\title{
Land Information System (LIS) for Land Administration and Management in Bangladesh
}

\author{
Kasphia Nahrin* \\ M. Shafiq-Ur Rahman**
}

\begin{abstract}
Bangladesh has a very high population density. Scarce land and the rapid increase of population of the country are creating high pressure over land-man ratio. Land ownership record system is insufficient and incomplete in Bangladesh. As a result, it spills out jumbled and spontaneous land development throughout the country, especially in the major cities. In this situation, it is important to establish a compatible land administration and management system for establishing a systematic approach for planned land development. Land Information System (LIS) is the most accountable and feasible systematic approach for developing an up-to-date land administration and management. LIS is related to various quantitative and qualitative aspects of land resource. Holding different cartographic information, LIS facilitates capturing, retrieval, and querying of information and provides tools to perform different analyses. Based on the secondary information by literature review, this paper is aimed at studying the existing land administration system, and recommending feasible interventions and strategy of LIS for creating an efficient land administration and management policy for Bangladesh. This paper also focuses on the challenges of LIS that are needed to be resolved for framing the existing land administration and management policy for planned and controlled growth of Bangladesh.
\end{abstract}

\section{Introduction}

Bangladesh, a South-Asian developing country is characterized by very high population growth and scare land. It spills out jumbled and spontaneous land development within urban areas as well as other areas within the country. The rapid increase of population is continuously reducing the land-man ratio of the country. The rate of land transfer and land conversion is also very high in Bangladesh. Rapid population growth combined with fast rate of land transformation urges for an effective land administration and management system. However, the conventional land administration system cannot keep pace with the growing demand and changing situation of the land market. Inappropriate land administration and management system is the cause for unplanned growth, and this eventually generates problems in community life. Inadequate and improper land records increase difficulties in the security of land tenure and land transfer. For this, it becomes an obligation to establish a compatible land administration and management system by setting up a holistic approach. Land Information System (LIS) is the most feasible systematic approach for developing an efficient land administration and management system in Bangladesh. This paper focuses on the issues that are needed to be addressed in formulating a viable land administration and management policy for the planned and controlled growth in Bangladesh.

\section{Objectives and Methodology}

The main objective of the study is to determine potentialities of LIS for an effective land administration and management system in Bangladesh. Critically analyzing the pitfalls of present system in the country, the paper attempts to address the potentialities of introducing LIS.

* $\quad$ Lecturer, Department of Urban and Regional Planning, Jahangirnagar University, Dhaka

** Assistant Professor, Department of Urban and Regional Planning, Jahangirnagar University, Dhaka 
The research is mainly based on secondary information. In this context, the research reviews the existing land administration and management system in Bangladesh. Actions to face challenges in the preparation and maintenance of land records by LIS in Bangladesh are developed through studying the concepts and basic elements of LIS from different literature.

\section{An Overview of Present Land Administration and Management in Bangladesh}

At present, three different Ministries practice land administration and management in Bangladesh, namely Ministry of Land (MoL); Ministry of Law, Justice and Parliamentary Affairs (MLJPA); and Ministry of Establishment (MoE). Land record system in Bangladesh forms an integral part of land administration, encompassing preparation of Record-of-Rights (ROR) through surveying and mapping of land plots, registration of deeds during transfer of land and updating ownership records. Directorate of Land Record and Survey (DLRS) under the MoL prepares ROR. However, updating of ROR (mutation) is done by the Upazila Administration which is under the jurisdiction of MoE. Furthermore, registration of transfer deed is under obligation of Registration Department that is under the MLJPA. Land record preparation, upgrading of ROR and land transfer registration are the integral parts of land administration and these should be coordinated well enough. However, these offices work separately with little coordination among them (Aziz, 2003).

The DLRS is entrusted with the responsibility of carrying out cadastral surveys and preparation of ROR. A revised mauza map showing location, area and characteristics and a khatian indicating ownership, area and character of land are the two parts of ROR. The DLRS conducts surveys and settlement operations through Zonal Settlement offices and Upazila Settlement offices. A survey team consisting of two Surveyors and one Chainman conduct the survey operation. The steps of hearing objections and appeal are done by Sub-Assistant Settlement Officer (SASO) and Assistant Settlement Officer (ASO) respectively (Aziz, 2003). Survey operation consists of the following phases: traverse survey, Kistwar (Plot to Plot) survey, preliminary record writing (Khanapuri), demarcation of boundary, local explanation (Bujharat), attestation (Tasdik), draft publication, disposal of objection, appeals, final Junk (checking), printing and publication of Khatian (Ahmed, 1994). Furthermore, revisional settlement for upgrading land record is undertaken by the settlement offices. Land records that have been prepared through revisional settlement operation are reliable (Siddiqui, 1997).

Land registration is a deed of maintenance of a public register, which is a record of an isolated transactions. Sub-Register (SR) registers transfer of any parcel of land through a deed with stamp on the property value as Immovable Property Transfer Tax (IPTT). When any deed is registered in Registration office, Land Transfer (LT) notice is to be sent to the Office of Assistant Commissioner's (AC, Land) Office (Aziz, 2003). Mutation is the process of revising and updating the ROR on transfer of land ownership and on subdivision and amalgamation of landholdings. The AC (Land) working under Deputy Commissioner (DC) updates or revises partially these land records through mutation process. There are two ways of mutation (Siddiqui, 1997):

i) Mutation according to LT; and

ii) Mutation in response to application to the Upazila Land office.

After the finalization of land records in survey operation the DLRS sends khatians, mauza maps to the DC office that preserves them in the District Record Room. At present, a Record Room is also maintained in the AC (Land) Office. These Land Records provide the base to conduct further survey and preparation of master plan, structure plan, infrastructure development plan, valuation of property tax, etc. Furthermore, these records are used as the base for functioning of public and private development and by the companies providing utility services. 


\section{Problems of Present Land Administration and Management in Bangladesh}

At present the responsible ministries and agencies involved for land management and administration work independently with little coordination among them. The whole process is manual, laborious and time intensive. Conventional methods of land survey, preparation and upgradation of land records, maintenance of all related data for each parcel of land makes land administration and management incomplete and inefficient. Moreover, distortion of land records at various stages (i.e. plot-to-plot survey, preparation of records and drawing of maps through conventional methods, objections, junk / checking works, printing, etc.) hinders land development control and property tax collection.

Khatians are not conclusive evidence of ownership, merely provide basis for possession at the recording time. Under the prevailing legal system, khatians along with deeds and mutated documents together are relevant for ownership decision by a Civil court (Mia, 1996). The lengthy and complex process of ownership determination enhances conflicts. The present system of registered transfer deed of land does not prove ownership or transferable rights of the seller rather put risk of false transfer (Aziz, 2003). Deeds are full of unnecessary, irrelevant and meaningless words that make them difficult to understand. Isolated maintenance of registration deeds and delay for sending LT notices to the AC (Land) office by the Registration office makes mutation and eventually the upgrading of ROR a lengthy procedure. As a result, it requires revisional settlement for updating land record that is more complex and time consuming. All the current stages of conventional preparation of ROR are vulnerable to tampering and distortion.

Inadequate and improper land registrations increase difficulties in land security tenure and land transfer in Bangladesh, as deed system does not provide the final proof of the proprietary right (Alam, 1992; Hossain, 1995). There is no provision of compensation if any loses occur to some person due to mistakes or errors in the deed. These results large-scale fraud and forgery related to land sale registration (Alam, 1992). There is notable corruption in Registration Office. If certain rate is not paid to the officers and staffs of the office, the deed is not placed before the SubRegistrar for registration. There is also a tendency of reporting lower price of land during the time of registration for avoiding IPTT or overpricing for getting the favour for finding bank loan for land development. It is an open secret that applicants are compelled to pay an extra amount of money than government settled charge in Tehshil office in the time of mutation. The mutation records can be distorted either during survey and settlement operations or due to false report of the Tehsildars.

Inadequate capacity of the Settlement Press for printing land records and poor quality of record maintenance also aggravate the inefficiency of the existing system. Many valuable records in Record Room have become worn out due to continuous use over a long period of time. Lack of the systematic and updated source of information has made the existing land record system more complicated and ambiguous that results innumerable land disputes and malpractice. Even government is continuously being deprived of her own (khas) land as grabbers manipulate ownership through forged documents (Barakat, 2001).

\section{Rationality of LIS based Land Administration and Management in Bangladesh}

Land administration and management system is too much complicated in Bangladesh. For efficient and appropriate land management program, maintenance of updated land ROR is very much important. It is easy to facilitate quick capturing, retrieval, and querying by holding different cartographic information by LIS. This provides different tools to perform different analyses. As a result, LIS could suit with the spontaneous land conversion and title change in the country. 
Once an accurate geodetic framework and cadastral system has been developed, many analysis of land-tenure change could be preformed with the assurance of high degree of measurement accuracy. This attempts to arrive at compatible multiple land uses within selected parcel of land (Demers, 1999). Land administration and management, land use control, provision of utility services and other services can be pursued by computerized LIS. This system would serve unified services related to land management by marginal labor, time and money. Use of LIS for recording and maintaining the original volume of land records could minimize the chances of tampering of records.

LIS could introduce Unified cadastre that is a broader concept to incorporate information related to positioning of land, land size and orientation, land ownership, land use etc. This is a large scale, community oriented land information system to serve both public and private organizations concerned to land administration and management, land development and service provision.

\section{Concept of Land Information System}

Geographic Information System (GIS) is defined as collection of data, storage and analysis with relation to their spatial distribution at various stages of information handling (Figure 1). LIS is a bifurcation of GIS. When data in the GIS is related to various quantitative and qualitative aspects of land resource, it is termed as Land Information System (LIS). LIS is most often based on the ownership, management, and analysis of portion of the earth most frequently of interest to human.

LIS is further subdivided into parcel and non-parcel based. Non-parcel based LIS include natural resources information system. Activities within the non-parcel based LIS could include habitat, evaluation, conservation easement procurement, wildlife evaluation, earthquake and landslide prediction, flood hazard abatement, chemical contamination evaluation, forest and range management, and scientific investigation. Parcel-based LIS application is generally focused on land ownership and other cadastral investigations (National Academy of Sciences, 1983).

Fundamental applications of the earlier mentioned types are highly accurate geodetic framework upon which the percales can be precisely described. LIS application involves traditional survey methods and Global Positioning System (GPS), a sophisticated satellite system for acquiring the local information (Demers, 1999). The Cadastral Survey (CS) and Mapping methodology based on ground survey or aerial survey supplemented by ground survey is to be adopted. Completion of these operations would provide digital mauza maps (Aziz, 2003). Figure 01 describes the concept of a land information system, where different agencies make a series of overlapping maps or other media of information based on common identifiers.

Satellite navigation systems or Global Positioning system (GPS) could be used for field data collection. For this, the surveyors use portable backpack or hand-held devices. They use signals from GPS satellites to work out this exact location on the earth's surface in the terms of $(x, y, z)$ co-ordinates using trigonometry at the push of a button of the GPS receiver. Most GPS receivers store collected co-ordinates and associated attribute information in their internal memory, so they can be downloaded directly into a GIS database (Heywood, et. al. 2002).

\section{Fundamental Elements of Land Information System}

Fundamental elements for a LIS-based cadastral mapping system are as follows:

\section{Geographic Control Data}

Geographic control data describes the coordinate system of all data in the GIS that is used to reference where things are located. Major road intersections or property subdivision boundary corners could be used for spatial reference. 


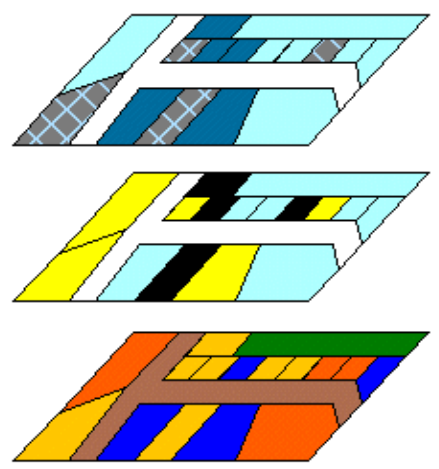

Average hous ehold in come

$\square$ High

$\square$ Medium

$\square$ Low

Population density

High

$\square$ Medium

$\square$ Low

Land us e

$\square$ Residential $\square \quad$ Industrial

Commercia $\square$ Recreational

$\square$ In frastructure

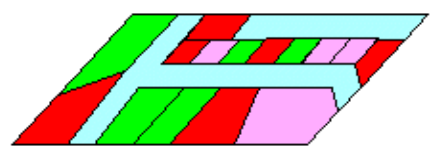

Land value

$\square$ High $\square$ Low

$\square$ Medium $\square$ No value

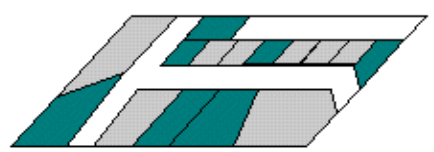

Land Owners hip

$\square$ Freehold

$\square$ Leasehold

$\square$ Public ownership

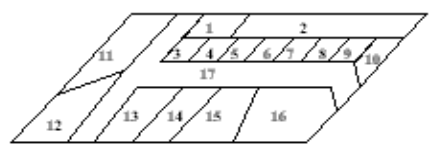

B asic parcels

Source: Dale and McLaughlin, 1988.

Figure 01: The concept of LIS

\section{Cadastral Data}

Cadastral data are the spatial information describing each plot containing area, use, plot number, plot boundaries together with location expressed in terms of mauza, upazila and district. These delineate all cadastral parcels and display a unique Identification Number (IN) for each of them and relate the parcel to attribute information.

\section{Attribute Data}

Attribute data are additional information about geographic control base map data, cadastral information, and other mapped features. For example, Ownership Rights expressed in terms of name and address of the owners, share of the plot, other interests in a plot that include appurtenances, mortgages and leases against the plot along with Identification Number (IN). Attribute data are stored in a database.

The following parts of the papers attempt to provide some recommendations for preparation and maintenance of land information by LIS.

\section{Preparation of Land Information System}

Figure 2 shows the steps with the actors that could work for preparation of land record with LIS. In the preliminary stage, satellite image could be an important source for determining land use of areas i.e. river, house, cropland. These satellite images and the conventional land record could be used as base map for conducting survey to prepare LIS. For preparation of unified cadastre the 
first step is to establish geodetic survey control network i.e. Upazila under collaboration of Upazila Settlement office and AC (Land) Office. This network provides unique reference framework. The Survey Team (ST) comprising surveyors of the Upazila Settlement Office with the joint venture of Private Survey Companies would prepare Land Record. The conventional survey method would be substituted by GPS for field data collection and mapping. AC (Land) as well as the Zonal Settlement Officer would facilitate this team with guidance and monitoring.

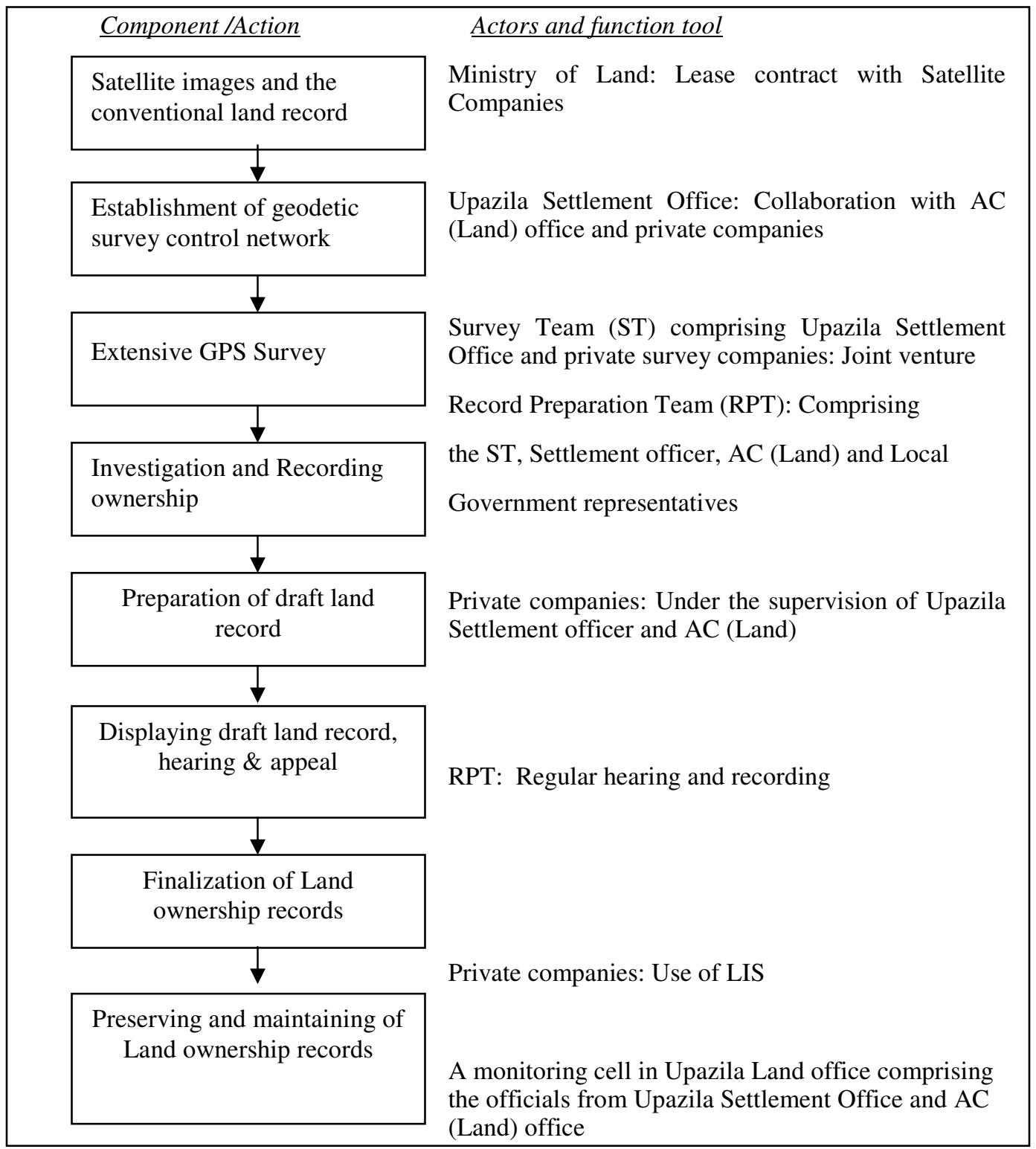

Source: Developed by Author, 2008

Figure 2: Steps (actions) for preparation of land record

After establishing plot descriptions, the next step will be recording ownership in each plot. Ownership will be determined through investigation of the documents and other forms of evidence 
of ownership presented by the owner. RPT would comprise of the ST, Zonal officer, AC (Land) and Local Government representatives (Upazila Parishad Chairman and members). The team would collect evidence of possession and ownership of land in open meetings within a given period of time. Alongside ownership rights, the same team will determine other interests relating to lease, mortgage, encumbrances and appurtenance using various sources. Then private companies would prepare draft land record within a short period by using GIS software.

Draft land record will then be displayed in the notice boards inviting objections, from all who are concerned within a specific period. Complaints would be heard by RPT. There would be scope for appeal. Hearing and appeal would be confined to a definite timeframe to avoid unusual delay. After disposal of appeal, the private companies would finalize unified land ownership records and prepare LIS for data management within a given time. Landowners would get printed final copies of land record with IN. Upazila Land office would preserve the master copies as well as the softcopy with sufficient computer networking for information sharing with DLRS and DC Office.

\section{Maintenance of Land Information System}

A monitoring cell of Upazila Land Office comprising the officials from Upazila Settlement office and AC (Land) office, headed by Land Record Officer (LRO) would continuously update ownership records for changes during transfer, inheritance or inclusion of other rights. This point provides some suggestions to maintain LIS for land administration.

\section{Transfer through sale}

Landowners requiring transfer of ownership would apply addressing LRO in a simple prescribed form showing IN of land and particulars. Registration Officer would prepare computerized deed of land transfer with stamp duty and tax on the basis of verification of LRO from the database of LIS. LRO would update Land record accommodating ownership changes through the information form registration office by computerized information networking simultaneously.

\section{Inheritance and other rights}

Recording changes of ownership due to inheritance and other rights involves submission of an application in simple prescribed form to LRO. Updating records of plot boundaries as a result of subdivision or amalgamation would start with an application in a prescribed form to LRO. Surveyors of Upazila Settlement Office would verify it on the ground level with the help of GPS. By continuous updating by this way, there would not require intervening settlement functions and mutation. Comparison between conventional land record and proposed system would make proposed land administration and management system by LIS more understandable. Table 1 highlighted the major similarities and contrasts between LIS with the existing land administration system.

\section{Example of Applying GIS in Land Administration}

In Singapore, twelve government agencies have cooperated in integrating land-related data in digital form with financial assistance from UNDP and UNCHS. The Land Data Hub contains information (statistics, descriptions, maps etc) on cadastral boundaries, building outlines, and topographic data as well as sewerage, drainage and telephone networks. Substantial cost savings have been made by avoiding work duplication and data inconsistencies. Standardized data can now easily be integrated with local data kept by each agency. Various agencies are responsible for the continuous supply and updating of data to a support unit located in a central ministry which is supposed to harmonize the data. The agencies meet regularly to agree on common policies and procedures (Paulsson, 1992). 
Table 1: Comparison between conventional land record and proposed system

\begin{tabular}{|c|c|c|}
\hline Features & Existing system & Proposed system \\
\hline $\begin{array}{l}\text { Form of Surveying and } \\
\text { mapping. }\end{array}$ & $\begin{array}{l}\text { Centralized system by DLRS at } \\
\text { Zone (Old District) level. }\end{array}$ & $\begin{array}{l}\text { Decentralized at Upazila level with } \\
\text { collaboration of Settlement offices, } \\
\text { AC(Land) and private companies. }\end{array}$ \\
\hline Survey method & Traverse survey, chain survey etc & Satellite image, GPS \\
\hline Nature of Surveying & Periodic and seasonal. & Regular and continuous. \\
\hline $\begin{array}{l}\text { Composition of a } \\
\text { Survey team. }\end{array}$ & $\begin{array}{l}\text { Mostly seasonal temporary } \\
\text { employees headed by a Surveyor. }\end{array}$ & $\begin{array}{l}\text { Surveyor of Settlement office, officials } \\
\text { from Upazila Land office, staff of private } \\
\text { companies }\end{array}$ \\
\hline Information Access & Manual and time-consuming. & $\begin{array}{l}\text { Computerized LIS (i.e. with GIS } \\
\text { software), continuous }\end{array}$ \\
\hline Record preparation & $\begin{array}{l}\text { Manual, periodic and time } \\
\text { consuming }\end{array}$ & $\begin{array}{l}\text { Computerized LIS (i.e. with GIS } \\
\text { software), regular }\end{array}$ \\
\hline Updating records & $\begin{array}{l}\text { Periodic updating and lengthy } \\
\text { mutation. }\end{array}$ & Continuously updating by LRO \\
\hline Land Registration & $\begin{array}{l}\text { Isolated function by Registration } \\
\text { Department. }\end{array}$ & $\begin{array}{l}\text { Integrated with LRO and registration } \\
\text { officer during transfer. }\end{array}$ \\
\hline Mutation & $\begin{array}{l}\text { Though LT notice, time } \\
\text { consuming }\end{array}$ & Continuous with land transfer registration \\
\hline $\begin{array}{l}\text { Ownership Rights/ } \\
\text { ROR }\end{array}$ & $\begin{array}{l}\text { Khatian, deed and mutated } \\
\text { documents are together } \\
\text { determinants of ownership. }\end{array}$ & Unified Land record \\
\hline $\begin{array}{l}\text { Other Rights and } \\
\text { Encumbrances. }\end{array}$ & $\begin{array}{l}\text { Clouded, ambiguous, irregular } \\
\text { updating }\end{array}$ & Continuously updating by LRO \\
\hline $\begin{array}{l}\text { Community } \\
\text { Participation. }\end{array}$ & Unlikely & Local Government bodies assist RPT \\
\hline $\begin{array}{l}\text { Land administration and } \\
\text { management }\end{array}$ & $\begin{array}{l}\text { Settlement, Management and } \\
\text { Registration are three disjointed } \\
\text { streams. }\end{array}$ & $\begin{array}{l}\text { Settlement, Management and } \\
\text { Registration streams are unified through } \\
\text { information sharing. }\end{array}$ \\
\hline
\end{tabular}

\section{Challenges/Key Issues for Introduction of LIS in Bangladesh}

For introducing computerized LIS some key issues are needed to be resolved, such as reorganizing existing land recording system to suit with LIS, setting up appropriate legal procedures for resolving inherent and other form of land right. Moreover, it is a great challenge for introducing necessary skill and training for developing human resource, a financial commitment and last of all the political will. Therefore, implementation of LIS is not a simple matter as it involves in general the following legal, political and technical issues that are needed to be resolved before introduction of LIS.

\section{Legal}

Existing land administration and management law is not responsive to the practice of LIS. It needs extensive review and update of the existing land policies, organizational set up for land management to cope with new ROR system. 


\section{Institutional}

In every political period, the importance for attaining an accurate, up-to-date and easily accessible land record system has been emphasized. However, in practice, for variety of reasons the land administration and management of the country are still in dilapidated state. There is lack of interministerial and interdepartmental coordination for the functions of land registration, record preparation, settlement operation and record maintenance. It is a great challenge to integrate all of the responsible Ministries, departments and offices extensively to deal with the LIS.

\section{Technical}

It would require technical equipments, such as computer, software, GPS receiver, printer, scanners and so on for introduction of LIS. Moreover, highly technical and skilled professionals would be essential for conducting survey, computerized database management, computer networking, land record preparation, updating records due to land sale or inheritance or other activities for LIS. Lack of trained and qualified surveyors, cartographers, specialists and computer programmers in Bangladesh is a major barrier for effective survey and mapping for LIS.

\section{Financial}

Technical equipments and skilled staff are very expensive. It would be a great challenge to manage the huge monetary fund for extensive survey, mapping, database management, organizational arrangement and other tasks for introducing LIS in Bangladesh.

\section{Some Guiding Issues}

For effective land administration and management, diversified information related to land could be unified by LIS. This unified land record system needs the conciliation and cooperative attitude of the land record and survey and other concerned organizations. Though there are a number of underlying challenges for introduction of LIS for land administration and management system in Bangladesh, sufficient steps could bring possible solution.

Necessary legislative framework should be prepared to support the proposed cadastral system to meet user requirements, to redefine the roles of the government, industry and academia for supporting LIS. The officials concerned with its preparation and recording have to be legally authorized to conduct proceeding and make ownership vesting orders. The Registration Act should be modified to make ownership checking as a mandatory obligation before registration. The revenue laws of the country should be modified, simplified and practicably and pragmatically uniform throughout the country for better land administration.

If land administration and management responsibility is vested to single agency, it could increase the responsibility of the agency. Eventually, the existing management practice and legal procedure reform could bring the risk of a chaotic situation. The unified land record system with LIS could be set with the present institutional arrangement with minimum extension and modification of the functioning of the responsible agencies. For this, it will need to change the mindset of the responsible public agencies to work in an coordinated manner to cope with LIS.

Designated public or private body of experts and professionals could conduct feasibility studies to assess the magnitude of cost inputs needed to conduct GPS surveys and computerization of land records by LIS for the entire country. Based on the financial implications, a conscious and determined effort could be made to distribute the costs among all the interest groups of LIS through viable and realistic financing system. Joint ventures or partnerships among government, the private industries, academic institutions and international organizations could facilitate in every steps of the proposed system.

Unified land record for whole of the country with LIS would be a gigantic task. Computerized unified cadastre may be initially introduced in a small area as a pilot project. On the evaluation of the result, a nationwide up-to-date LIS system could be implemented in full-fledge or in step-bystep. If necessary, there could be some modifications in the system before further progression with LIS in the country. 
To reduce the labor and time of survey, the latest record could be used as the base map and areas that have outdated record would be better to build a fresh land record directly in digital form by GPS. At the stages of preparation of unified land record should maintain time-bound approach. Well-organized, appropriate and effective training could increase potentiality of the professionals. Trained workforce would escalate the proper implications of the new system.

Extensive privatization of cadastral survey and land records computerization in LIS could be effective. Government could assess the efficiency of private sectors in various stages of land record preparation, updating and maintenance. Furthermore feasibility studies on different forms of public-private partnerships or full privatization could increase effectiveness of LIS. Transparent and accessible data to the general public would increase the acceptability of LIS. For this purpose, community involvement could be increased.

\section{Conclusion}

Land administration and management system in the country is very complex and time consuming. LIS could bring an appropriate land administration and management in Bangladesh. However, the initiatives of LIS would face a great challenge regarding the legal and institutional matters of the country as well as for technical constraints. LIS responsive land reform, institutional arrangement, extensive privatization, sufficient training, and the over all political will would be needed for introducing the new system. Despite the huge installation and recurring cost of new technologies, once the land record is completely computerized, various space-specific parameters could be hooked-up to the land record. The same record could be utilized for various purposes such as taxation, subdivision planning and other tasks in urban, rural and regional level. For this purpose, demand responsive step-by-step approach within a timeframe would bring the effective results for land administration and management through LIS.

\section{References}

Ahmed, K.U. 1994. Land Survey Methods and Technical Rules, Dhaka: Payara Prokashani, p. 26.

Alam, M. S. 1992. "Land Records, Registration and Land Tax" in N. Islam (ed.), Urban Land Management in Bangladesh. Dhaka : Ministry of Land.

Aziz, M. A. 2003. Land Record System in Bangladesh: An Analysis of Problems and Possible Solutions, available at http://www.google.com.bd/search?q=Land+Information+System+in +Bangladesh\&hl= en\&start $=10 \& s a=N$, accessed on 20 February 2008.

Barakat, A. 2001. Political Economy of Khas Land in Bangladesh, Dhaka: BRAC, p.229.

Dale, P. F. and McLaughlin. 1988. Land Information Management: An Introduction with Special Reference of Cadastral Problems in Third World Countries, Oxford : Clarendon Press.

Demers, M. N. 1999. Fundaments of Geographical Information Systems, New Mexican State University.

Heywood, I.; Cornelius, S.; and Carver, A. S. 2002. An Introduction to Geographical Information Systems, Singapore: Pearson Education.

Hossain, T. 1995. Land Rights in Bangladesh - Problem of Management. Dhaka: The University Press Limited.

Mia, S. R. 1996. Rules on Mutation. Dhaka: Naya Dunia Publication,, p. 66.

National Academy of Sciences. 1983. Procedures and Standards for a Multipurpose Cadastre. Panel on a Multipurpose Cadastre, Committee on Geodesy, Commission on Physical Science, Mathematics and Resources, National Research Council, National Academy Press, Washington, D. C.

Paulsson, B. (1992). Urban Applications of Satellite Remote Sensing and GIS Analysis. Washington D.C.: World Bank/UNCHS/UNDP.

Siddiqui, K. 1997. Land Management in South Asia- a Comparative Study. Dhaka: The University Press Limited. 